\title{
PHYSICAL SELF-CONCEPT AND SELF-ESTEEM IN ADOLESCENTS AND YOUNG ADULTS WITH AND WITHOUT PHYSICAL DISABILITY: THE ROLE OF SPORTS PARTICIPATION Stefano Scarpa, Ph.D *
}

\author{
* Department of Educational Sciences, University of Padua, Italy
}

The present study aims to investigate the role of physical activity and sports participation on physical self-concept and self-esteem in adolescents and young adults with and without physical disability. The participants were 1149 individuals aged between 13 and 28 (578 boys and 571 girls). They were divided into four groups: (A) without disability who practised sport $(\mathrm{n}=742)$, (B) without disability who did not practise sport $(\mathrm{n}=264),(\mathrm{C})$ physical disabled who practised sport $(\mathrm{n}$ = 109), (D) physical disabled who did not practise sport $(\mathrm{n}=34)$. The participants completed the Physical Self-Description Questionnaire (PSDQ; Marsh, Richards, Johnson, Roche, \& Tremayne, 1994) in a cross-sectional design. The results highlighted that individuals with physical disability who practised sport obtained similar results to the people without disability who practised sport in a ten of the eleven PSDQ scales. Finally it seems possible to assert that persons with physical disability who practise sport present a positive physical self-concept and good self-esteem.

KEYWORDS: Physical Self-Concept, Physical Disability, Sport, Adolescence

\section{INTRODUCTION}

Self-concept is one of the most researched constructs within the framework of educational psychology, psychology of the personality, and social psychology. Selfconcept can be defined as the perception that an individual has of him or herself, with contents that are both descriptive, as well as evaluative (Harter, 2003, 1999). As far as Fox (1998) affirms, self-concept refers to how an individual perceives him or herself, or the self-described profile based on a multitude of roles and attributes that we believe make up one's own self. The three main characteristics of the construct are multi-dimensionality, hierarchy, and stability. Self-concept is comprised of various dimensions (social, physical, and academic), that pose themselves in a hierarchical manner, in order to construct the global self and have an influence on selfesteem. The stability of self-concept, in a global form, refers to the fact that it is not easily susceptible to change (Marsh \& Yeung, 1998).

Corporeal self-recognition constitutes a component of self-concept that is not easy to define in unambiguous terms.
However, it can be affirmed that corporeal self-recognition constitutes an ensemble of knowledge, feelings, memories, and experiences that the individual uses to refer to his or her body (Fox, 1998). Physical selfconcept is considered a multidimensional subdomain of the overall self-concept that incorporates different characteristics, such as physical activity, fitness conditions, health and appearance (Marsh, Richards, Johnson, Roche, \& Tremayne, 1994). It should be also mentioned that Fox and Corbin (1989) suggested the multidimensional organization of the physical self (sport competence, physical condition, body attractiveness and physical strength) and the role of physical self-worth as mediator between these dimensions and self-esteem. According to Fox (1990) and Marsh (1994), the multidimensional and hierarchical characterization of physical self-concept can be represented by a three level model with self-esteem at the top, global physical selfconcept at the second level, and specific components of physical self-concept at the third level. 
In the field of sport and exercise, physical self-concept is also considered a psychological construct with an impact on physical activity. It plays a considerable role in determining results (Carraro, Scarpa, \& Ventura, 2010).

Scientific evidence shows that physical selfconcept is 'built' by the individual in his/her evolution under the influence and interdependence of three main components, i.e. somatic, psychological and social components. The development of physical self-concept is not influenced only by the data which attest an individual's physical structure, or only by the mere psychological, emotional and affective vision of one's physicality, but by the close interaction of these two components with the social dimension (Cash, Thériault, \& Annis, 2004; Shapiro \& Martin 2010a).

Physical self-concept plays a crucial role during adolescence and youth. In these phases of life, individuals experience many changes in their body. Sex differences become evident and boys achieve higher performance levels in most physical skills (Fletcher \& Hattie, 2005; Harter, 2003, 1999). During adolescence and youth it is very important to have a positive physical self-concept in order to promote individual well-being (Maïano, Ninot, \& Bilard, 2004).

Some studies showed that children and young adults with disabilities have fewer friends, experience more loneliness and are more teased and/or neglected compared to those without disabilities. Furthermore, individuals with disabilities often receive negative 'feedback' related to their body, which contributes to the development of a poor body image (Arbour, Latimer, Martin Ginis, \& Jung, 2007; Martin, 2006; Martin \& Mushett, 1996; Martin \& Smith, 2002). Individuals with physical disabilities generally have a more negative physical self-concept than other people, but people with physical disability involved in regular sports practise can report higher levels of physical self than sedentary individuals without disability (Ferreira \& Fox, 2008).
As reported by Martin in a recent congress, some sentences typical of people with physical disability are the following: "My disability makes my body look bad", "Well, my disability certainly makes me feel less attractive. I mean, if you're in a wheelchair, you won't have a great body with toned muscles" (Martin, 2010).

Indicated below, in an analytical manner and in chronological order, are the results and the implications of the study that was conducted in the past few years regarding the role of sports and adapted physical activities in creating self-concept and, more in general, the dimensions of psychological well-being correlated to such, in individuals with physical disabilities.

Campbell (1995) conducted a study with the scope of evaluating the differences in psychological well-being among individuals in wheelchairs with congenital and acquired disabilities who participate in a sport. Psychological well-being was evaluated through points relevant to humor, generalized anxiety, self-esteem, and sense of mastery. According to this study, athletes in wheelchairs with acquired disabilities later in their lives present a better state of well-being than those with congenital disabilities.

Blinde \& McClung (1997) tried to evaluate the impact of participating in recreational activities on the perception of physical selfconcept and social self-concept in individuals with physical disabilities. The analysis of the interviews conducted in the study of the two researchers showed that participating in recreational activities, such as swimming, fitness, tennis, and so on, has an impact on four factors of corporeal self-recognition: (a) experimenting one's own body in new ways; (b) increasing the perception of one's own physical attributes; (c) redefining one's own physical capacities; (d) increasing the confidence perceived in facing new physical activities.

The contribution given by Groff \& Kleiber (2001) intended to verify the belief according to which participating in sports is tied to developing the identities of adolescents with 
physical impairments. The results of the study showed that adapted sports contribute to improving the perception of one's own abilities and skills, as well as emotional expression, and social attractions, while decreasing the perception of a disability.

Tasiemski, Kennedy, Gardner, \& Blaikley (2004) studied the development of the athletic identity in individuals with spinal lesions. In analyzing the results of their study, the authors suggest that the lowest athletic identity related by athletes with spinal lesions could be attributed to social evaluations that seem not to justify the conditions of the physically disabled individual as an athlete.

Ferreira \& Fox (2008), in their study, proposed analyzing multiple aspects of physical self-perception in male basketball players with and without disabilities. In particular, the results of the study showed that playing sports while in a wheelchair contributed to a positive development of physical self-esteem, further furnishing a unique opportunity to successfully perform complex sports activities. The sports context resulted as being extremely important for individuals with disabilities, assisting them in finding opportunities to experiment with new challenges, evaluate their own capabilities, gain confidence and a positive vision of their own corporeality, as well as experiment successful situations when exposed to social evaluations. Athletes with physical impairments who participated in sports activities, therefore, had greater confidence towards their own bodies, a greater sense of attraction, and a positive opinion with respect to the abilities of their bodies in their sports performance.

Recognizing the growing importance of adapted sports for individuals with disabilities, the objective of the Anderson (2009) study was that of using the construct of symbolic interactionism for examining the development of the identities of adolescent girls with physical disabilities who participated in forms of organized sports in wheelchairs, with particular reference to the study of development of the athletic identity.
The results of the study showed a role of primary importance in the participation in recreational activities, such as sports for developing personal identity.

Shapiro \& Martin (2010a) examined the athletic identity, the loved ones, and the relations among equals in young athletes with physical disabilities. The results of the study showed that friendships created within and without sports for the disabled can contribute to improving the quality of life, and promoting positive emotional states, such as a sense of joy, satisfaction, inspiration, excitement, and enthusiasm.

In the same year, Shapiro \& Martin (2010b) published a study with the scope of describing the multi-dimensional self-concept (example: strength, resistance, and skills in sports) in athletes with physical disabilities. Among the main results, what was emphasized was that the perception of physical self-recognition in the participants determined their general selfesteem for at least $50 \%$. The other $50 \%$ could probably be attributed to other dimensions of self-concept (academic, emotional, social). Of extreme relevance seemed to be the areas related to flexibility, strength, and resistance, with a strong influence on general selfconcept. In summary, the results of the study showed that participants with a more positive concept of their corporeal self-recognition, as well as of their strength, resistance, and flexibility, also demonstrated greater selfesteem with respect to those who had obtained lower points for these four variables. Sport practice can contribute to developing a positive physical self-concept in persons with physical disabilities (Arbour, et al., 2007). Sport can have a positive effect on the physical self-concept of people with physical disabilities, not only improving their physical condition (e.g. increased strength and endurance) and their psychological well-being (e.g. decreased anxiety and depression, increased self-esteem and self-efficacy), but also creating opportunities for meaningful social interactions - e.g. increased social support and friendship, (Blinde \& McClung, 1997; Campbell, 1995; Martin, 2006; Martin, \& Smith, 2002). 
The present study aimed at investigating the role of sport participation for the development of physical self-concept in individuals with physical impairment. In particular we had three aims: (1) to describe physical selfconcept in adolescents and young adults (aged between 13 and 28) with physical disability (only one previous study investigated the multidimensional physical self-concept in adolescent and young athletes; Shapiro \& Martin, 2010b), (2) to analyze the differences between individuals with disability and individuals without disability (a previous study investigated this point in a sample of adult individuals; Ferreira \& Fox, 2008), (3) to analyze the differences between individuals who regularly practice sport ( $1 / 1.5$ hours for session, 2/3 times at week) and individuals who do not practice any sport (there are no previous studies investigating point 2 and point 3 in adolescents and young adults). Therefore, the objectives of this study were those of analyzing the multiple aspects of physical self-concept in a sample of adolescents and young adults between the ages of 13 and 28 and comparatively analysis the four groups divided on the basis of the interaction of the variables regarding "sports performance" (yes/no) and the "presence of physical disabilities" (yes/no).

Based on the rationale existing in the literature, we hypothesize that adolescents and young adults with physical impairment show lower levels of perceived physical self than their peers without disability. We also hypothesize that adolescents and young adults who regularly practice sport present higher levels of physical self-concept than their peers that are not involved in sport activities. Finally, we hypothesize that adolescents and young adults with physical impairment who regularly practice sport present similar levels of physical self-concept than their peers involved in sport activities that are without disability.

\section{METHODS}

\section{Participants}

A convenience sample was engaged in the present study. The eligibility criterion for the sport groups was the regular practice of sport for one year or more (1/1.5 hour for session, $2 / 3$ times at week). The eligibility criterion for the participation of disabled people was the presence of peripheral (spinal cord injuries) or central (cerebral palsy) paraplegia. The eligibility criterion for the whole sample was being aged between 13 and 28. In this study, it was decided not to only consider the adolescent stage, since nowadays "youth" is intended as that stage of life, which extends the times of non-autonomy and independence beyond the traditional confines of adolescence. This is why the concept of "long adolescence" is largely used. We assist in the paradox where society obligates us to mature in an accelerated manner, on one hand, while on the other, it does not allow for solidifying the identity of a youth. Social and psychological studies show three main elements that lead to an extension of the youth stage in contemporary western societies: the extension of the period of schooling; the constant increase of professional and economic precariousness after having terminated school studies; the extension of the period of time continued living at home (Cavalli \& Galland, 1996).

If up until a decade ago the "youth" category could be easily opposed to the "adult" category, since the transition threshold that separated them was clear-cut and easily identifiable, today, we can assist in a breakage of this traditional opposition and the establishment of multiple types of intermediate situations, which cannot be easily 'categorized', and that are uncertain, ambiguous, and do not allow classification of an individual within the categories of adolescence and adulthood. Recognizing this objective limit, it is possible to relate the "youth" attribute to a broad and diversified age range (Milan, 2001): pre-adolescence (1114 years), adolescence (15-18 years), and youths (19-25 years and beyond).

So, one thousand two hundred twenty-five volunteers were recruited in the present study. After data collection, out of the 1225 participants, 76 had to be excluded from the analyses because they did not meet the 
eligibility criteria or there were data missing from their questionnaires. Thus, 1149 individuals (578 boys and 571 girls) participated in the study (mean age $=19.03$ ). They were divided into four groups: (A) without disability who practiced sport $(\mathrm{n}=$ $742 ; 378$ boys and 364 girls), (B) without disability who did not practice sport $(n=264$; 99 boys and 165 girls), (C) physically disabled who practiced sport $(\mathrm{n}=109 ; 84$ boys and 25 girls; 103 with spinal cord injuries and 5 with cerebral palsy), (D) physical disabled who did not practice sport ( $\mathrm{n}=34 ; 17$ boys and 17 girls; 30 with spinal cord injuries and 4 with cerebral palsy).

As can be noted by the numeric distribution of the four groups, at a first glance, there seems to be a disproportion. That is, the number of non-disabled individuals is decidedly greater than that of disabled individuals. However, is this disproportion real or not? If reference is made to the principles that are at the foundation of sampling strategies, what is emphasized is that the disproportion is inverse. For better clarification, with respect to the population of reference, which our sample wants to represent, disabled individuals are relatively greater in number, or better proportioned, than non-disabled individuals. According to a census conducted by the ISTAT (Italian National Institute of Statistics), there are 2,615,000 disabled individuals in Italy, of which 1,200,000 with a physical type of disability. Among those with physical disabilities, the estimate is of 50,000 paraplegics in Italy who are, above all, comprised of individuals under the age of 30 . If you take into consideration that there are $60,000,000$ number of Italian citizens, this implicates that paraplegics constitute $.08 \%$ of the population. In other terms, there is one paraplegic every 1,200 Italian citizens. To respect this proportion, we would have had to recruit 1,200 non-disabled individuals for each disabled individual. As is evident in the data, the number of non-disabled individuals is not 1,200 times greater than that of disabled individuals. Therefore, it is possible to sustain that participants with disabilities present in our sample are more than representative. With regards to non-disabled individuals, it can be considered that a number approximate to one thousand is more than sufficient for the statistical analysis to be conducted and, therefore, for meeting the objectives that were established in the study.

Lastly, it must be specified that, the fact that the number of disabled individuals who perform sports activities is lower than those who do not, constitutes a limit in this study. This was tied to the difficulty in recruiting disabled individuals for research who were not inserted in integrated contexts of life, since the population of the number of nonparticipants is greater with respect to those who participate in sports. However, this aspect will be elaborated on in the final section of the article, where the limits and future prospects of the research are explained.

\section{Measures}

Physical Self-Description Questionnaire $(P S D Q)$ - PSDQ was developed and validated by Marsh et al. (1994) to assess nine specific factors of physical self-concept and two global scales, placed at a higher hierarchical level: physical self-concept and self-esteem. In the present study we used an Italian version of the instrument, which is designed to measure the nine specific components of physical self-concept (activity, endurance, strength, flexibility, coordination, sport, health, body fat, appearance) and the two global components (global physical and global esteem) in a sample of 951 students (548 female and 403 male) aged between 11 and 36. Internal consistency and reliability was tested using as average Cronbach's Alpha $=.87$ and the relevance of existing indices reported by Scarpa, Gobbi, Paggiaro, \& Carraro, 2010 revealed a good adjustment of the original model to the Italian population with RMSEA $=.053$, NFI $=.965$, NNFI $=$ $.972, \mathrm{CFI}=.975, \mathrm{GFI}=.874, \mathrm{AGFI}=.852$, PGFI $=.744$. The invariance cross gender and age was also tested.

In the sample of the present study, Cronbach's Alpha scores for the eleven PSDQ scales were considered adequate $(\alpha=.73-.89$, in the whole 
sample, $\alpha=.72-.89$, in the group of participants without disability, $\alpha=.76-.92$, in the group of participants with physical disability). Exploratory Factor Analyses (EFA) was used to test the model in the group with physical disability. Kaiser-Myer-Olkin (KMO) was adequate (.915). The eleven factors of the PSDQ explained $73.44 \%$ of all variance in the items. Factors loadings for PSDQ items was acceptable for the eleven scales: activity (.67-.88); endurance (.51-.76); strength (.59-.64); flexibility (.48-.76); coordination (.39-.77); sport (.59-.71); health (.73-.77); body fat (.88-.91); appearance (.62$.74)$; global physical (.58-.75); global esteem (.34-.63). The scores of factors loadings for PSDQ items seemed to confirm the factor structure and to make it possible to assume that the model structure would be similar in the group of individuals with physical impairment.

After the administration of the PSDQ, participants were asked to report some essential personal information such as their gender, age, weight $(\mathrm{kg})$, height $(\mathrm{m})$, kind of sport, type of physical disability (peripheral or cerebral paraplegia).

\section{Procedures}

Participants completed the PSDQ in a crosssectional design. Participants completed questionnaires individually and they were reassured that they responses would remain confidential. The treatment of all participants was in accordance with the ethical standards of the APA. Written consent was obtained from all participants and participant' parents (in the case of minor participants).

In order to ensure that PSDQ was appropriate for the two groups of disabled people, 7 people with physical disability were consulted in the pre-research stage. For example, the sentence of the sixth item ("I can run a long way...") was changed with the following sentence: "I can cover long distances...".

The research was carried out through the entire Italian territory, with the support of several students from the degree course in Physical Activity and Sport Sciences of the Universities of Padova and Urbino. With regards to non-disabled participants, students were involved who attended middle schools, high schools, and degree courses in Physical Activity and Sport Sciences, Primary Education, Medicine, and Surgery from the two Italian universities stated above. In relation to disabled participants, all paraplegic associations in Italy were contacted (personally, by phone, or by e-mail). Furthermore, particular attention was given to our research conducted on the 'www.superando.it' website, which added the questionnaire to a web page set up with the explanation of the research, along with the possibility to fill out the questionnaire and send it to the researchers.

\section{Statistical analysis}

All analyses were performed using SPSS (version 18.0). Coefficient Alpha was calculated for each of the 11 scales on the PSDQ. Descriptive statistics (mean and standard deviation) were performed in order to describe physical self-concept in the four groups. The analysis of variance (one-way ANOVA) with a post-hoc test (Bonferroni) was conducted to examine the differences between the four groups on the PSDQ scales. The multivariate analysis of variance (MANOVA) was conducted to examine the interactions between the four groups and other independent variables (gender, age; kind of impairment: spinal vs cerebral; sport type: individual $v s$ team) on the PSDQ scales. Linear regression analysis was conducted to assess the influence of physical activity (independent variable) on global physical (dependent variable) both in individuals with physical impairment and in individuals without disability.

\section{RESULTS}

\section{Descriptive Statistics and Analysis of Variance}

Descriptive statistics of age, weight $(\mathrm{kg})$, height $(\mathrm{m})$ are presented in Table 1 for each group.

Table 2 contains the descriptive statistics for the PSDQ variables. Analysis of variance (Table 3) showed significant differences 
between groups in the following PSDQ scales: activity $\left(\mathrm{F}_{3,1145}=350.2, \mathrm{p}<.0001\right)$, endurance $\left(\mathrm{F}_{3,1145}=67.7, \mathrm{p}<.0001\right)$, strength $\left(\mathrm{F}_{3,1145}=34.4, \mathrm{p}<.0001\right)$, flexibility $\left(\mathrm{F}_{3,1145}=\right.$ $13.3, \mathrm{p}<.0001)$, coordination $\left(\mathrm{F}_{3,1145}=52.3\right.$, $\mathrm{p}<.0001)$, sport $\left(\mathrm{F}_{3,1145}=117.6, \mathrm{p}<.0001\right)$, health $\left(\mathrm{F}_{3,1145}=6.4, \mathrm{p}<.0001\right)$, body fat $\left(\mathrm{F}_{3,1145}=16.1, \mathrm{p}<.0001\right)$, appearance $\left(\mathrm{F}_{3,1145}\right.$ $=4.6, \mathrm{p}=.003)$, global physical $\left(\mathrm{F}_{3,1145}=\right.$ $18.1, \mathrm{p}<.0001)$, and global esteem $\left(\mathrm{F}_{3,1145}=\right.$ $20.1, \mathrm{p}<.0001)$.

Table 1 Description of the sample (age, weight, height)

\section{ND-SPORT ND-NoSPORT D-SPORT D-NoSPORT}

$$
\mathrm{n}=742 \quad \mathrm{n}=264 \quad \mathrm{n}=109 \quad \mathrm{n}=34
$$

Variable Mean SD Mean SD Mean SD Mean SD

\begin{tabular}{lrrrrrrrr}
\hline Age (years) & 17.03 & 4.54 & 17.76 & 4.99 & 19.83 & 4.62 & 19.01 & 4.71 \\
Weight (kg) & 55.35 & 13.20 & 55.39 & 11.99 & 65.77 & 13.49 & 61.65 & 15.23 \\
Height (m) & 1.66 & .101 & 1.64 & .102 & 1.70 & .132 & 1.61 & .173
\end{tabular}

Note. ND-SPORT = not disabled who practiced sport; ND-NoSPORT $=$ not disabled who did not practice sport; D-SPORT = physical disabled who practiced sport ; D-NoSPORT = physical disabled who did not practice sport.

Table 2 Descriptive Statistics for PSDQ Scales in the four Groups

\section{ND-SPORT ND-NoSPORT D-SPORT D-NoSPORT}

$$
\mathrm{n}=742 \quad \mathrm{n}=264 \quad \mathrm{n}=109 \quad \mathrm{n}=34
$$

\begin{tabular}{lrrrrrrrr} 
Scale & Mean & SD & Mean & SD & Mean & SD & Mean & SD \\
\hline Activity & 4.4 & 1.2 & 1.9 & 1.0 & 4.1 & 1.3 & 1.9 & .9 \\
Endurance & 4.1 & 1.3 & 2.9 & 1.4 & 4.2 & 1.2 & 3.0 & 1.4 \\
Strength & 4.0 & 1.2 & 3.3 & 1.2 & 4.3 & .9 & 3.2 & 1.3 \\
Flexibility & 3.8 & 1.2 & 3.4 & 1.2 & 3.9 & 1.0 & 3.0 & 1.2 \\
Coordination & 4.4 & .9 & 3.8 & .9 & 4.0 & 1.0 & 3.0 & 1.1 \\
Sport & 4.5 & 1.0 & 3.3 & 1.2 & 4.4 & .9 & 2.7 & 1.3 \\
Health & 5.3 & .8 & 5.1 & 1.0 & 5.0 & 1.0 & 4.7 & 1.3 \\
Body Fat & 4.9 & 1.3 & 4.4 & 1.4 & 4.3 & 1.6 & 4.0 & 1.8 \\
Appearance & 4.1 & 1.1 & 3.9 & 1.1 & 4.2 & 1.0 & 3.7 & 1.1 \\
Global Physical & 4.6 & 1.3 & 4.1 & 1.2 & 4.4 & 1.2 & 3.7 & 1.3 \\
Global Esteem & 4.7 & .8 & 4.4 & .9 & 4.9 & .7 & 4.0 & 1.3
\end{tabular}

Note. $N D$-SPORT = not disabled who practiced sport; ND-NoSPORT = not disabled who did not practice sport; D-SPORT = physical disabled who practiced sport; $D-N o S P O R T=$ physical disabled who did not practice sport. 
Table 3 Analysis of Variances for PSDQ Scales in the four Groups

\begin{tabular}{lrrrr}
\hline Scale & ANOVA & & \multicolumn{2}{c}{ Effect } \\
& $\mathrm{F}$ & $d f$ & $p$ & Size \\
\hline Activity & 350.2 & 3,1145 & $<.0001$ & .479 \\
Endurance & 67.7 & 3,1145 & $<.0001$ & .151 \\
Strength & 34.4 & 3,1145 & $<.0001$ & .083 \\
Flexibility & 13.3 & 3,1145 & $<.0001$ & .034 \\
Coordination & 52.3 & 3,1145 & $<.0001$ & .121 \\
Sport & 117.6 & 3,1145 & $<.0001$ & .236 \\
Health & 6.4 & 3,1145 & $<.0001$ & .017 \\
Body Fat & 16.1 & 3,1145 & $<.0001$ & .041 \\
Appearance & 4.6 & 3,1145 & .003 & .012 \\
Global Physical & 18.1 & 3,1145 & $<.0001$ & .045 \\
Global Esteem & 20.1 & 3,1145 & $<.0001$ & .050 \\
\hline
\end{tabular}

Note. Effect size was calculated using the quadratic $r$ index (95\% CI).

\section{Bonferroni Post-Hoc Results}

The Bonferroni post-hoc analysis revealed that group A (not disabled - sport) scored higher than group B (not disabled - no sport) and group D (disabled - no sport), but did not differ from group $\mathrm{C}$ (disabled - sport) in the following PSDQ scales: endurance, flexibility, coordination, sport, appearance, global physical and global esteem. It also indicated that group C (disabled - sport) scored higher than group A (not disabled sport) in the strength PSDQ scale and that group D (disabled - no sport) got the lowest scores of all in the coordination, sport, and global esteem PSDQ scales.

\section{Multivariate Analysis of Variance}

The results of the MANOVA indicated no significant interaction between independent

variables on the PSDQ scale, with the exception of flexibility when considering gender differences. Female participants were significantly more flexible than male participants $\left(\mathrm{F}_{1,1147}=2.7, \mathrm{p}=.043\right)$.

\section{Linear regression analysis}

Linear regression analysis highlights a subtle but significant influence of physical activity on global physical in both physical impairment group (Coefficient $=.31$; Standard Error $=.02 ; \mathrm{t}=10.5 ; \mathrm{R}^{2}=.15 ; \mathrm{F}_{1,141}$ $=30.7 ; \mathrm{p}<.0001)$ and without disability group $($ Coefficient $=.39$; Standard Error $=.05$; $\left.\mathrm{t}=5.5 ; \mathrm{R}^{2}=.09 ; \mathrm{F}_{1,1003}=109.2 ; \mathrm{p}<.0001\right)$.

\section{DISCUSSION}

The purposes of this study were to describe the participants' physical self-concept, to assess the differences between disabled and non-disabled groups and to analyze the role of sports participation on physical self-concept. Comparison between the four groups supported the hypothesis that adolescents and young adults who regularly practice sport present higher levels of physical self-concept 
than their peers who are not involved in sports activities and that adolescents and young adults with physical impairment who regularly practice sport present similar levels of physical self-concept than their peers involved in sport activities that are without disability.

The internal consistency of the PSDQ scales was good for the whole sample, both for the non-disabled group and for the disabled group, as shown by Cronbach's Alpha scores. Results from EFA supported the validity of the Italian version of the PSDQ when used with people with physical disability.

Descriptive statistics showed that group A (non-disabled - sport) and group C (disabled sport) had moderate to strong self-concept scores (Shapiro \& Martin, 2010b), whereas group B (not disabled - no sport) and group D (disabled - no sport) had lower self-concept scores than the other two groups (with the exception of health scale for 'not disabled no sport' group). A visual examination indicates that group B (not disabled - no sport) and group D (disabled - no sport) had the lowest score in the physical activity scale $(\mathrm{M}=1.9)$. Participants who practiced sport had moderate to strong self-concept scores as they ranged from slightly under 4 to over 5 on the 6-point scale. Participants without disability who practiced sport had the lowest score for flexibility (i.e., 3.8) and the highest for health (i.e., 5.3). Similarly, participants with physical impairment who practiced sport had the lowest score for flexibility (i.e., 3.9) and the highest for health (i.e., 5.0). Finally, a visual examination of the descriptive statistics indicates that group C (disabled - sport) had higher mean scores than group A (nondisabled - sport) in endurance (i.e., 4.2), strength (i.e., 4.3), flexibility (i.e., 3.9), appearance (i.e., 3.9), global esteem (i.e., 4.4). The analysis of variance and the Bonferroni post-hoc test revealed that individuals with physical disability who practiced sport obtained similar results to the group of people without disabilities who practiced sport in all the PSDQ scales with the exception of body fat, whereas the disabled group that did not practise sport obtained the worse PSDQ scores in comparison with the other three groups in the following PSDQ scales: coordination, sport, self-esteem.

Participants with physical disability who practiced sport viewed themselves in a similar way to participants without disability who practiced sport. In particular they did not show significant differences in the following dimensions of physical self-concept: endurance, flexibility, coordination, sport, appearance, global physical, and self-esteem.

A surprising result was that individuals with physical impairment who practiced sport perceived themselves to be stronger than those without disabilities without disabilities who practiced sport. A similar result was found by Ferreira and Fox (2008) in basketball players. Probably, pushing a wheelchair every day and using it in sports has a powerful influence on perceived strength.

Participants with physical disabilities who did not practice sport viewed themselves as less active, with lower endurance, strength, flexibility, coordination and sport performance, less attractive and possessing a worse physical concept. They had a lower self-esteem in comparison with participants with physical disability who practiced sport. Sports participation is an essential behavior for the maintenance of functional independence and can improve the quality of life (Heath \& Fentem, 1997), furthermore sport behavior can improve self-esteem in individuals with physical disability (Martin, 2007) also by enhancing perceptions of physical attributes, increasing perceived confidence in new physical activity, expanding social interactions and doing social activities in inclusive contexts (Blinde \& McClung, 1997; Shapiro \& Martin, 2010b).

Finally, as we can see in Figure 1, the participants who practiced sport generally exhibited a more positive physical selfconcept than the other participants (regardless of the presence or absence of disability). They viewed themselves as more physically active, better in endurance performances, stronger, more flexible, more coordinated, better at sports, having a better appearance, possessing 
a better corporeality and a higher self-esteem than those who did not practice sport. The only two physical self-concept dimensions in which practicing sport did not seem to lessen the influence of disability were body fat and health. Athletic, disabled people saw themselves possessing the same body fat of disabled people not practicing sports.

Furthermore, sport practice does not seem to be a sufficient factor to make athletic disabled people feel healthier than disabled people not practicing sports (Scarpa, Gobbi, \& Carraro, 2010).

The results of the MANOVA seem to confirm gender differences in flexibility not only in the sample of people without disability but also in the sample of people with physical impairment. The fact that females perceived more flexible than males could be explained by many well-known genetic and cultural or behavioral factors (Carraro, Scarpa, \& Ventura, 2010).

Linear regression analysis results provide additional illumination in predicting the influence of physical activity on global physical self-concept. Physical activity (i.e., being physically active, doing lots of physical activities regularly) accounted for $15 \%$ of the variance in global physical (i.e., feeling positive about one's physical self) for participants with physical impairment. Physical activity seemed to play a more important role for people with physical disability than in people without disability in determining physical self-concept $(15 \%$ vs. $9 \%$ of the variance).

In conclusion, it is possible to assert that persons with physical disability who practice sport present a positive physical self-concept and a good self-esteem. The fact of being physically active seems to positively influence physical self formation. The sport context constitutes an important background where individuals with physical disability find opportunities to test their capacities, highlighting ability rather than disability. The sport arena also creates opportunities to experience exposure to social assessment in integrated environments and can contribute to formulate stronger views of their bodies in people with physical disability. Sports and adapted physical activities can be considered, for people with disabilities, as fundamental opportunities for inclusion helping to improve the perception they have of their corporeality and, furthermore, contributing to improving their self-esteem. (Anderson, 2009; Blinde \& McClung, 1997; Ferreira \& Fox, 2008; Fox, 1988; Groff \& Kleiber 2001).

Figure 1 95\% Confidence Interval Graphs for PSDQ Scales in the four Groups
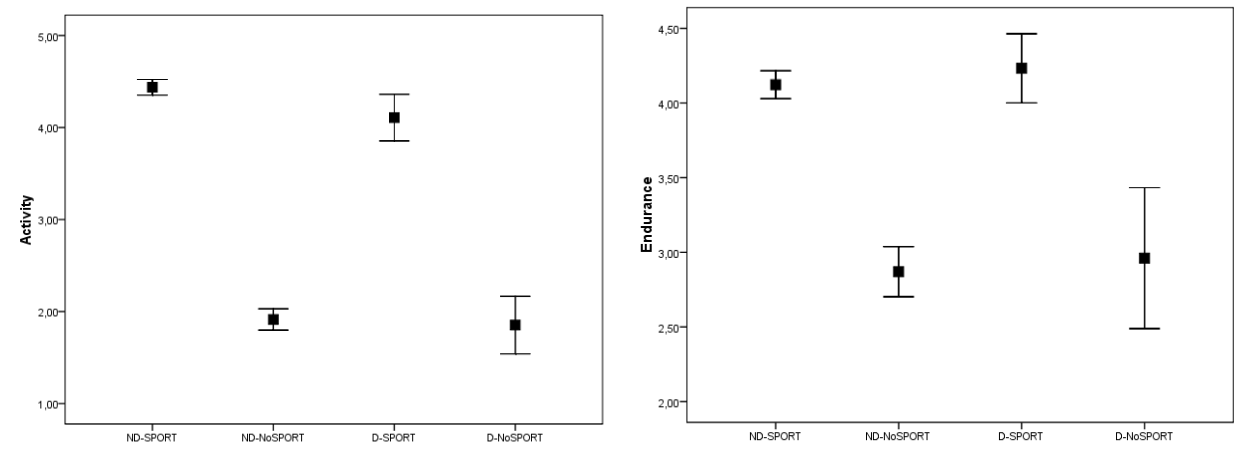

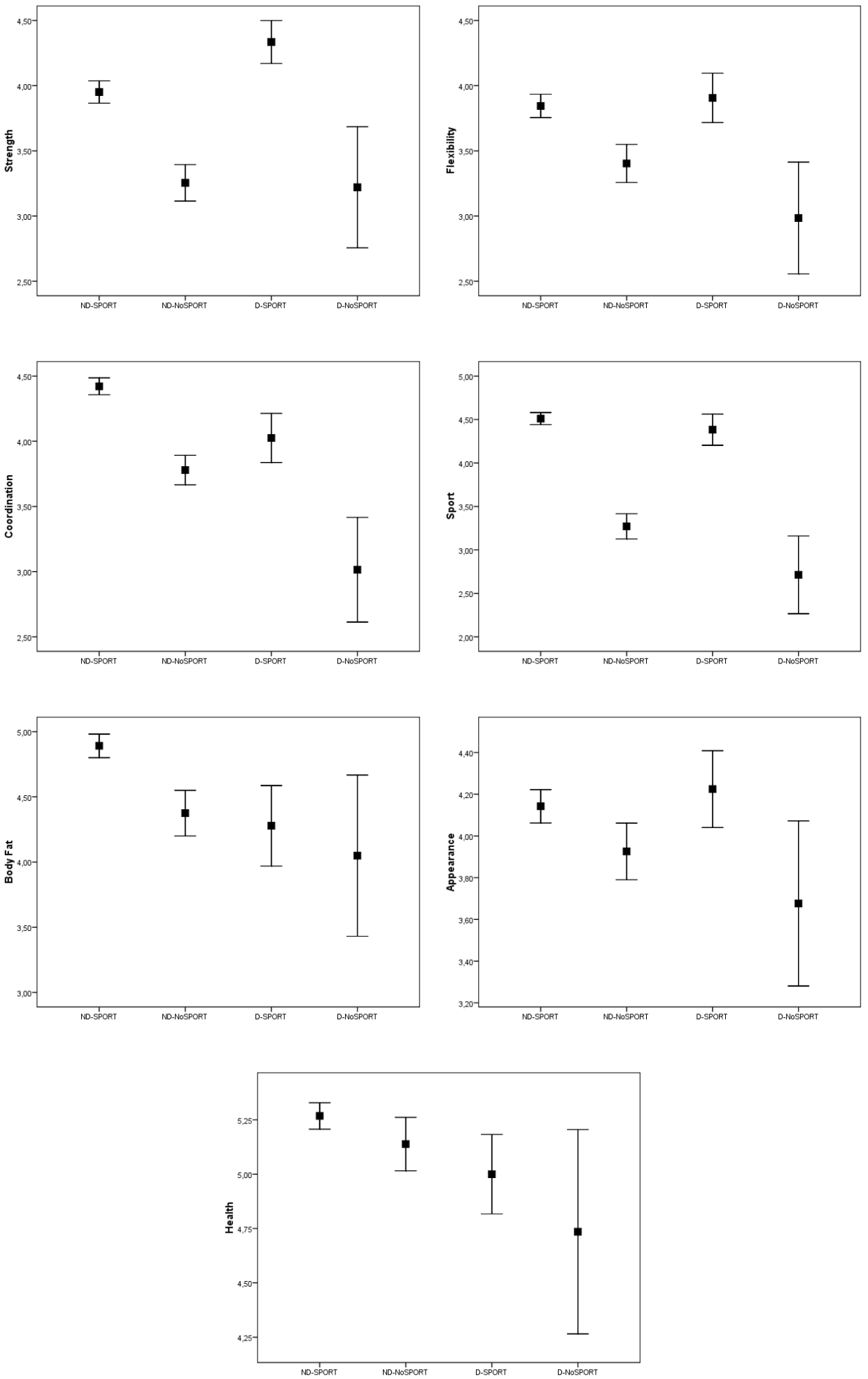

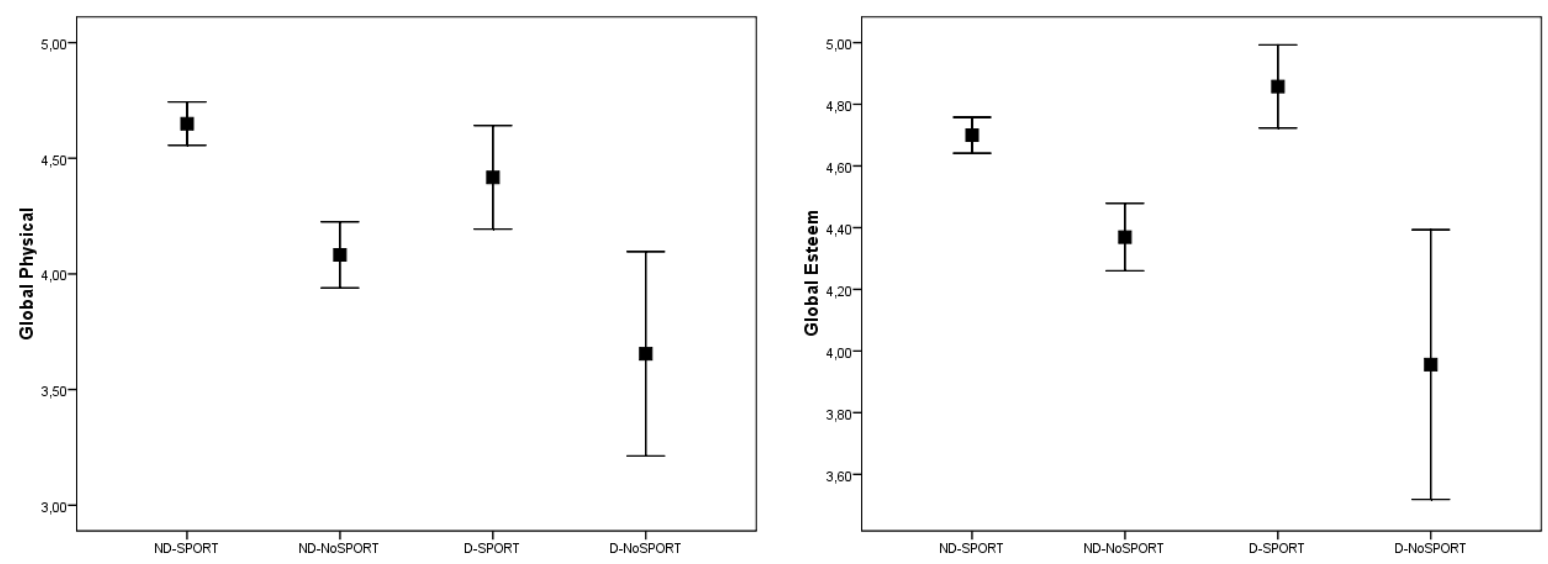

Note. ND-SPORT $=$ not disabled who practiced sport; ND-NoSPORT $=$ not disabled who did not practice sport; D-SPORT = physical disabled who practiced sport; D-NoSPORT = physical disabled who did not practice sport.

\section{Limitations and Directions for Future Research}

A significant difference in sample size over the different groups indicates caution in drawing conclusions on the hypotheses of this study and in generalizing the results. One of the limitations of this study is the relatively low number of participants in the group of disabled people who did not practice sport, especially if we take into account that inactivity among people with physical impairment is very high. This fact is mainly due to the difficulty of recruiting people with disabilities who are not included in social institutions such as sports clubs. On the other hand, it seems possible to assume that people who are not included in social structures also have a worse physical self-concept in comparison with 'included' disabled people (Martin \& Mushett, 1996). Furthermore, this fact highlights the need to increase opportunities for adolescents and youth with physical impairments to practice sports in "fully integrated" contexts (Groff \& Kleiber 2001).

This study was based on a cross-sectional design. In the future it would be interesting to investigate, in more detail, the role of sports practice in the physical self-concept of individuals with physical disability through a longitudinal research design.
There is a significant number of potential covariates that require further investigation. In future it would be interesting to investigate the effects of the following variables on physical self-concept building: the age of the onset of disability, the role of family, the role of personality, the motivation to practice sport (Campbell, 1995; Tasiemski, et al., 2004).

Finally, further research based also on qualitative studies could provide new important suggestions about the peculiar formation process of physical self-concept in groups with physical impairments.

\section{REFERENCES}

Anderson, D. (2009). Adolescent girls' involvement in disability sport: Implications for identity development. Journal of Sport \& Social Issues, 33, 427449.

Arbour, K.P., Latimer, A.E., Martin Ginis, K.A., \& Jung, M.E. (2007). Moving beyond the stigma: The impression formation benefits of exercise for individuals with a physical disability. Adapted Physical Activity Quarterly, 24, 144-159.

Blinde, E.M., \& McClung, L.R. (1997). Enhancing the physical and social self through recreational activity: Accounts of individuals with physical disabilities. 
Adapted Physical Activity Quarterly, 14, 327-344.

Campbell, E. (1995). Psychological well being of participants in wheelchair sports: Comparison of individuals with congenital and acquired disabilities. Perceptual and Motor Skills, 81, 563-568.

Carraro, A., Scarpa, S., \& Ventura, L. (2010). Relationships between physical selfconcept and physical fitness in Italian adolescents. Perceptual and Motor Skills, 110, 522-530.

Cash, T.F., Thériault, J., \& Annis, N.M. (2004). Body image in an interpersonal context: adult attachment, fear of intimacy, and social anxiety, Journal of Social and Clinical Psychology, 23, 89103.

Cavalli, A., \& Galland, O. (1996). Senza fretta di crescere. L'ingresso difficile nella vita adulta. Napoli: Liguori.

Ferreira, J.P.L., \& Fox, K.R. (2008). Physical self-perceptions and self-esteem in male basketball players with and without disability: A preliminary analysis using the physical self-perception profile. European Journal of Adapted Physical Activity, 1, 35-49.

Fletcher, R.B., \& Hattie, J.A. (2005). Gender differences in physical self-concept: A multidimensional differential item functioning analysis. Educational and Psychological Measurement, 65, 657-667.

Fox, K.R. (1998). Advances in the measurement of physical self. In J.L. Duda (Ed.), Advances in sport and exercise psychology measurement, Morgantown: Fitness Information Technology, 295-310.

Fox, K.R. (1990). The Physical SelfPerception Profile Manual. DeKalb, IL: Office for Health Promotion, Northern Illinois.

Fox, K.R. (1988). The self-esteem complex and youth fitness. Quest, 40, 230-246.

Fox, K.R., \& Corbin C.B. (1989). The Physical Self-Perception Profile: Development and preliminary validation. Journal of Exercise and Sport Psychology, 11, 408-430.
Groff, D.G., \& Kleiber, D.A. (2001). Exploring the identity formation of youth involved in an adapted sports program. Therapeutic Recreational Journal, 35, 318-332.

Harter, S. (2003). Beyond the debate: Why some adolescentes report stable self-worth over time and situation, whereas others report changes in self-worth. Journal of Personality. 71, 1027-1058.

Harter, S. (1999). The construction of the self: A developmental perspective. New York: Guilford Press.

Heath, G.W., \& Fentem, P.H. (1997). Physical activity among persons with disabilities - A public health perspective. Exercise and Sport Sciences Reviews, 25, 195-234.

Maïano, C., Ninot, G., \& Bilard, J. (2004). Age and gender effects on global selfesteem and physical self-perception in adolescents. European Physical Education Review, 10, 53-69.

Marsh, H.W. (1994). The importance of being important: Theoretical models of relations between specific and global components of physical self-description. Journal of Sport \& Exercise Psychology, 16, 306325.

Marsh, H.W., Richards, G., Johnson, S., Roche, L., \& Tremayne, P. (1994). Physical self-description questionnaire: Psychometric properties and multitraitmultimethod analysis of relations to existing instruments. Journal of Sport \& Exercise Psychology, 16, 270-305.

Marsh, H.W., \& Yeung, A.S. (1998). Topdown, bottom-up, and horizontal models: The direction of causality in multidimensional, hierarchical selfconcept models. Journal of Personality and Social Psychology, 75, 509-527.

Martin, J.J. (2010). The psychosocial dynamics of disability sport and exercise. XVIII AIPS Congress, 15-17 October Chieti/Italy, 1.

Martin, J.J. (2007). Physical activity behaviors and physical self-concept of individuals with physical disabilities. 
Journal of Human Movement Studies, 52, 37-48.

Martin, J.J. (2006). Psychosocial aspects of youth disability sport. Adapted Physical Activity Quarterly, 23, 65-77.

Martin, J.J., \& Mushett, C. (1996). Social support mechanisms among athletes disabilities. Adapted Physical Activity Quarterly, 13, 74-83.

Martin, J.J., \& Smith, K. (2002). Friendship quality in youth disability sport: perceptions of a best friend. Adapted Physical Activity Quarterly, 19, 472-482.

Milan, G. (2001). Disagio giovanile $e$ strategie educative. Roma: Città Nuova.

Scarpa, S., Gobbi, E., \& Carraro, A. (2010). The body in the mind: Role of sport practice on physical self-description in adolescents and young people with and without motor disability. $X V$ ECSS Congress, 23-26 June Antalya/Turkey, 416-417.
Scarpa, S., Gobbi, E., Paggiaro, A., \& Carraro, A. (2010). Un contributo alla validazione italiana del Physical SelfDescription Questionnaire Short. Giornale Italiano di Psicologia dello Sport, 8, 2530.

Shapiro, D.R., \& Martin, J.J. (2010). Athletic identity, affect and peer relations in youth athletes with physical disabilities. Disability and Health Journal, 3, 79-85.

Shapiro, D.R., \& Martin, J.J. (2010). Multidimensional physical self-concept of athletes with physical disabilities. Adapted Physical Activity Quarterly, 27, 294-307.

Tasiemski, T., Kennedy, P., Gardner, B.P., \& Blaikley, R.A. (2004). Athletic identity and sports participation in people with spinal cord injuries. Adapted Physical Activity Quarterly, 21, 364-378.

Corresponding author's e-mail address: stefano.scarpa@unipd.it

\section{(Abstract) \\ KÖRPER-SELBSTKONZEPT UND SELBSTWERTGEFÜHL BEI JUGENDLICHEN UND JUNGEN ERWACHSENEN MIT UND OHNE BEHINDERUNG: DIE ROLLE DER SPORTTEILNAHME}

Die vorliegende Studie hat die Absicht herauszufinden, welche Rolle Bewegung und Sportteilnahme für das physische Selbstkonzept und das Selbstwertgefühl bei Jugendlichen und jungen Erwachsenen mit und ohne Behinderung spielt. Die Teilnehmer(innen) (TN) waren 1149 Personen im Alter zwischen 13 und 28 Jahren (578 Buben und 571 Mädchen). Sie wurden in vier Gruppen geteilt: (A) TN ohne Behinderung, die Sport trieben $(n=742)$, (B) TN ohne Behinderung, die keinen Sport trieben $(n=264)$, (C) TN mit körperlicher Behinderung, die Sport trieben $(n=109)$, (D) TN mit körperlicher Behinderung, die keinen Sport trieben $(n=34)$. Die Teilnehmer(innen) beantworteten den Physical Self-Description Questionnaire (PSDQ; March, Richards, Johnson, Roche \& Tremayne, 1994) im Rahmen einer Querschnittsuntersuchung. Die Ergebnisse verdeutlichen, dass sporttreibende Personen mit körperlichen Behinderungen ähnliche Resultate erzielten wie sporttreibende Personen ohne Behinderung in 10 der 11 PSDQ-Skalen. Somit kann letztlich festgestellt werden, dass Personen mit Behinderung, die Sport betreiben, über ein positives Körper-Selbstkonzept und ein gutes Selbstwertgefühl verfügen.

Schlüsselwörter: Physical Self-Concept, körperliche Behinderung, Sport, Jugend 


\title{
(Résumé) \\ CONCEPT DU SOI PHYSIQUE ET ESTIME DE SOI CHEZ DES ADOLESCENTS ET JEUNES ADULTES AVEC OU SANS HANDICAP PHYSIQUE : LE ROLE DE LA PARTICIPATION SPORTIVE
}

Cette étude a pour but d'identifier le rôle de l'activité physique and la participation sportive en générale sur la perception physique de soi et l'estime de soi chez des adolescents ou jeunes adultes avec ou sans handicap physique. Au total, 1149 personnes âgées de 13 à 28 ans (578 garçons et 571 filles) ont participé à cette étude. Ils ont été divisé en quatre groupes : (A) sans handicap physique et pratiquant une activité sportive $(\mathrm{n}=742)$, (B) sans handicap physique et ne pratiquant aucune activité sportive $(\mathrm{n}=264),(\mathrm{C})$ handicapés physiques et pratiquant une activité sportive $(\mathrm{n}=109)$, (D) handicapés physiques et ne pratiquant aucune une activité sportive $(\mathrm{n}=34)$. L'ensemble des participants a répondu au questionnaire de perception physique de soi (Physical Self-Description Questionnaire, PSDQ; Marsh, Richards, Johnson, Roche, \& Tremayne, 1994) de manière transversale. Les résultats ont démontré que les personnes atteintes de handicap physique et pratiquant une activité sportive ont obtenu des résultats similaires pour neuf des dix échelles du PSDQ en comparaison avec les personnes n'ayant pas de handicap physique et pratiquant une activité sportive. En conclusion, nous pouvons affirmer que les personnes atteintes de handicap physique et pratiquant une activité sportive démontrent une perception physique de soi positive ainsi qu'une positive estime de soi.

MOTS CLES : Physical Self-Concept, le handicap physique, du sport, de l'adolescence

\begin{abstract}
(Аннотацця)
ФИЗИЧЕСКОЕ СОСТОЯНИЕ И САМООЦЕНКА ПОДРОСТКОВ И МОЛОДЫХ ЛЮДЕЙ С ИНВАЛИДНОСТЬЮ И БЕЗ: РОЛЬ ЗАНЯТИЙ СПОРТОМ.

Данное исследование направлено на изучение роли физической деятельности и спорта в определении физического состояния и самооценки подростков и молодых людей с инвалидностью и без. Участниками стали 1149 лиц в возрасте от 13 до 28 (578 мальчиков и 571 девочек). Они были разделены на четыре группы: (А) лица без инвалидности, занимающиеся спортом ( $\Pi=742)$, (В) без инвалидности, не занимающиеся спортом ( (C) физические инвалиды, которые занимались спортом (п = 109), (D) физические инвалиды, которые не занимались спортом (п = 34). Участники заполняли анкету на тему физического самочувствия (PSDQ; Марш, Ричардс, Джонсон, Роше, и Тремейн, 1994) . Результаты показали, что в десяти из одиннадцати случаев люди с физическими недостатками, занимающиеся спортом получили аналогичные результаты, как и лица, не имеющие инвалидности, но занимающиеся спортом. Наконец, представляется возможным утверждать, что люди с физическими недостатками, которые занимаются спортом, чувствуют себя позитивно и имеют хорошую самооценку.
\end{abstract}

КЛЮЧЕВЫЕ СЛОВА: Физические самооченку, физической инвалидности, спорт, Подростковый возраст 


\section{(Resumen) \\ AUTOCONCEPTO FÍSICO Y LA AUTOESTIMA EN ADOLESCENTES Y JÓVENES ADULTOS CON Y SIN DISCAPACIDAD FÍSICA: EL PAPEL DE LA PARTICIPACIÓN EN LOS DEPORTES}

El presente estudio tiene como objetivo investigar el papel de la actividad física y la participación deportiva en el autoconcepto físico y la autoestima en los adolescentes y jóvenes adultos con y sin discapacidad física. Los participantes fueron 1.149 individuos con edades comprendidas entre $13 \mathrm{y}$ 28 (578 niños y 571 niñas). Se dividieron en cuatro grupos: (A) sin discapacidad que practican deporte $(n=742)$, (B) sin discapacidad que no practican deporte $(n=264)$, (C) con discapacidad física que practicaba deporte $(\mathrm{n}=109)$, (D) con discapacidad física que no practicaron deporte $(\mathrm{n}=$ 34). Los participantes completaron el Cuestionario del Autoconcepto Físico (PSDQ; Marsh, Richards, Johnson, Roche, y Tremayne, 1994) en un diseño transversal. Los resultados pusieron de manifiesto que las personas con discapacidad física que practicaba deporte obtuvieron resultados similares para las personas sin discapacidad que practican deporte en diez de las once escalas del PSDQ. Finalmente, parece posible afirmar que las personas con discapacidad física que practican deporte presentan una autoconcepto físico positivo y una buena autoestima.

PALABRAS CLAVE: Autoconcepto físico, discapacidad física, el deporte, la Adolescencia

\section{(Resumo)}

\section{AUTO-CONCEITO FÍSICO E AUTO-ESTIMA EM ADOLESCENTES E JOVENS ADULTOS COM E SEM DEFICIÊNCIA FÍSICA: O PAPEL DA PARTICIPAÇÃO DESPORTIVA}

O presente estudo tem por objetivo investigar o papel da atividade física e a participação desportiva no auto-conceito físico e na auto-estima em adolescentes e jovens adultos com e sem deficiência física. Os participantes foram 1149 indivíduos com idades compreendidas entre 13 e 28 anos (578 rapazes e 571 raparigas). Foram divididos em quatro grupos: (A) sem deficiência que praticavam desporto ( $\mathrm{n}=742)$, (B) sem deficiência que não praticavam desporto $(\mathrm{n}=264),(\mathrm{C})$ com deficiência física que praticavam desporto $(\mathrm{n}=109)(\mathrm{D})$ com deficiência física que não praticavam desporto $(\mathrm{n}$ = 34). Os participantes completaram o Questionário de Auto-Descrição Física (PSDQ; Marsh, Richards, Johnson, Roche e Tremayne, 1994) num design transversal. Os resultados mostraram que os indivíduos com deficiência física que praticavam desporto obtiveram resultados semelhantes às pessoas sem deficiência que praticam desporto em dez dos onze itens da escala PSDQ. Finalmente, parece possível afirmar que as pessoas com deficiência física que praticam desporto apresentam um auto-conceito físico positivo e uma boa auto-estima.

PALAVRAS CHAVE: Auto-conceito físico, Deficiência Física, Desporto Adolescência, 